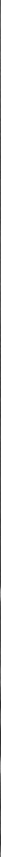

PROBOSCIS MONKEYS

\title{
Brunei Protects Its Wildlife
}

\section{Russe/l A. Mittermeier}

The people of Brunei know that they need to conserve the resources of their very small country. Proboscis monkey, clouded leopard, dugong, three sea turtles, eight hornbills and the earless monitor lizard are among the fully protected species; and there is little hunting. The people are Muslims, so many animals cannot be eaten. The Government controls timber extraction; no timber is exported and clear-felling is prohibited. So far there are no wildlife reserves, but, after investigating the potentialities of several uninhabited areas, including some mangrove islands, the author has made recommendations.

Brunei, a British protectorate scheduled to become independent in 1983 , is a tiny, oil-rich sultanate in north Borneo, covering 2226 square miles, between the Malaysian states of Sarawak and Sabah; a small strip of Sarawak divides it into two. Most of the 200,000 people are concentrated in and around the capital city of Bandar Seri Begawan and the oil-rich coastal region around Seria. Only a handful of aboriginal tribes occupy the interior, among them the Dusuns in Ulu Tutong and Belait, the Muruts in Temburong, and the Ibans in the upper regions of the Tutong, Belait and Temburong Districts.

Although Brunei does not yet have any national parks or sanctuaries, an important Wild Life Protection Enactment was passed in 1978, empowering the Sultan and his council to establish wildlife sanctuaries by decree, and 


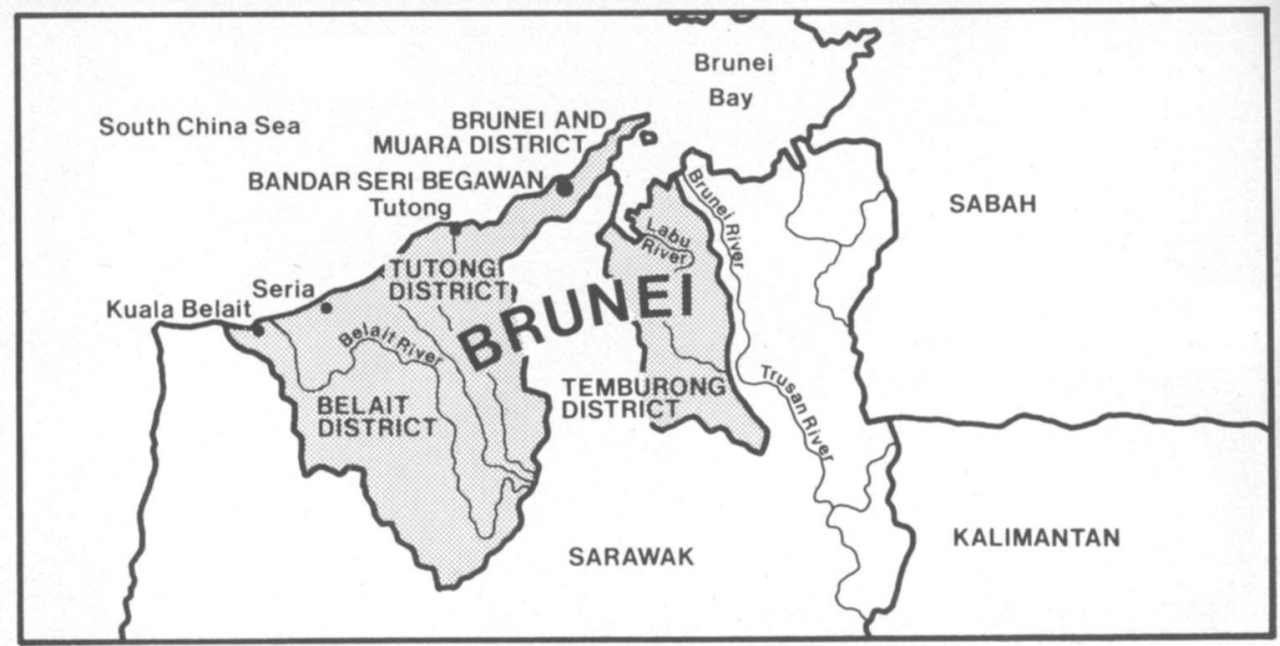

listing 34 protected species that cannot be hunted or exported without a special permit. These include proboscis monkey, clouded leopard, dugong, great argus pheasant, eight species of hornbills, three of sea turtles, and the earless monitor lizard. Lanthanotus. The export of wildlife was never important in Brunei, and this Enactment has ensured that it will not become a significant threat in the future.

Several other factors give Brunei an unusually high level of wildlife protection. First, people are largely devout Muslims and will not eat monkeys, pigs or many other animals. Secondly, guns have been prohibited since 1962, and the only hunting is in the interior, where people still use the traditional tribal methods to capture animals for food and for pets. Third, no timber is exported - in contrast to Sarawak, Sabah and Kalimantan - so that large-scale habitat destruction is not an issue in Brunei. Timber extraction for local consumption is allowed, but only in areas allocated by the government; clear-felling is prohibited. Areas already cleared for agriculture are being used more intensively, with a resultant decrease in shifting agriculture. Fourth, the people of this small country are beginning to realise that their forest and wildlife resources are limited and need to be conserved. Moreover, they are a well-educated people, and this, combined with their developing attitude towards conservation, means that future conservation education efforts are likely to be well received and effective. A particular effort is being made to educate young people by means of lectures and displays in schools, organised by the Brunei Museum's educational services.

Responsibility for wildlife conservation at present rests with the Brunei Museum, one of the finest in Asia, and its dynamic director, Dato Pengiran $M$. Shariffuddin. At his request the author conducted a brief survey of the nipa-mangrove islands in the immediate vicinity of Bandar Seri Begawan, and made recommendations for the establishment of several wildlife sanctuaries and possibly a mangrove national park in the Brunei Bay area. Except for the northern part of Pulau Berambang, the island nearest Bandar Seri Begawan, these islands are almost entirely uninhabited, and they have substantial populations of proboscis monkeys Nasalis larvatus, crab-eating macaques Macaca fascicularis, silver leaf monkeys Presbytis cristata, and a variety of birds. They are excellent examples of the nipa-mangrove associations characteristic of the north Borneo coast.

Especially interesting is the proboscis monkey, listed as vulnerable in the 


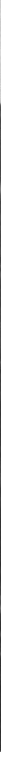

MANGROVES and NIPA PALMS (right)

Red Data Book and on Appendix I of both the Convention on International Trade in Endangered Species (CITES) and the US Endangered Species List. J.A. Kern, who studied them in the Brunei Bay area, found them to be still thriving, unaffected by the regular boat traffic or the close proximity of man, ${ }^{1}, 2,3$ and the author found the same in 1979. Indeed, one large group was seen within 100 metres of a small mainland village, and local people showed no interest in hunting or otherwise disturbing them. Proboscis also have potential as a tourist attraction, since they can easily be seen in early morning or late afternoon only 15 minutes by boat from the centre of Bandar Seri Begawan.

Another important coastal wildlife area is Pulau Siarau, an uninhabited island in Brunei Bay to the south-east of Bandar Seri Begawan and about an hour from the capital (by 25HP out-board motor): this is the roosting site for an enormous population of the large fruit bat Pteropus vampyrus. Every evening between 6 and $7 \mathrm{pm}$ they fly out in thousands to forage along the Brunei and Sarawak coasts. This island should certainly be made a wildlife sanctuary.

There is also potential for a large sanctuary or national park along the uninhabited stretch of coast between Pulau Siarau and the Sungei Labu (Labu Creek), and east to the Batang Trusan (Trusan River). This would encompass 
the entire coastal region of the smaller part of Brunei and would be a protected area of considerable international significance.

Several potential park sites also exist in the interior. The Brunei Museum expeditions of 1978 and 1979 to the Ulu Temburong region and South Labi, in the Ulu Belait region, revealed a large and uninhabited area of primary forest in the former, ranging between 500 and $6000 \mathrm{ft}$ and very rich in wildlife, and also an important, very scenic tract of lowland forest in the smaller South Labi area, adjacent to Sarawak's Gunung Mulu National Park. Both areas deserve special protection. The possibility of establishing parks or sanctuaries both in the interior and on the coast is being investigated.

Brunei's farsighted policies make it one of the best areas in Borneo and indeed in all south-east Asia for wildlife conservation, and the Government and the Brunei Museum are to be congratulated. Offical establishment of parks and sanctuaries will make these important wildlife areas secure for the future and give them the international recognition they deserve.

\section{References}

1. KERN, J.A. 1964. Observations on the habitats of the proboscis monkey, Nasalis larvatus (Wurmb), made in the Brunei Bay area, Borneo. Zoologica 49 (3): 183-92.

2. KERN, J.A. 1965a. The proboscis monkey. Animals 6: 522-6.

3. KERN, J.A. 1965b. Grotesque honker of the Bornean swamps - the proboscis monkey. Animal Kingdom 68: 67-73.

This article in the Brunei Museum Journal is reprinted by courtesy of the Director, Dato Pengiran M. Shaffiffuddin. It is Misc. Contrib no. 2 of the IUCN/SSC Primate Specialist Group.

Russell A. Mittermeier, Chairman, IUCN/SSC Primate Specialist Group and Director, WWF-US Primate Program, World Wildlife Fund - US., 1601 Connecticut Ave., NW, Washington, D.C. 20009; and Dept. of Anatomical Sciences, Health Sciences Center, Stony Brook, NY 11794.

\section{Mountain Gorilla Project in Rwanda: Education and Tourism}

An interested audience for an illusrated talk with pictures displayed on the side of the van.

Right Visitors with the habituated gorillas lan Redmond
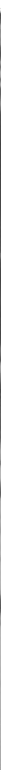